\title{
Research on the Problems of Human Resource Management in State-owned Enterprises and Reform ideas
}

\author{
Zhang Ruofan \\ School of politics and public administration, Soochow University, Suzhou, China \\ Email: 18896708516@163.com
}

Keywords: Human resources, State-owned enterprises (SOE), Question, Cause.

\begin{abstract}
Human resource management has become an important content of the development of contemporary social enterprises. Scientific development and management of human resources is an urgent need to study in the reform and development of state-owned enterprises in China. At present, the reform of state-owned enterprises in our country is at a critical stage. In order to extricate state-owned enterprises from the predicament and enhance the market competitiveness of state-owned enterprises, it is required to pay attention to and face squarely the problems existing in human resources management. So that the present situation of human resource management of state-owned enterprises and the causes of the problems can be analyzed, to make up for it in time, so as to create a good foundation for the reform and development of state-owned enterprises. The key to the development and growth of enterprises depends on the quality of people. The root of development is the power source of development. The quantity, quality and allocation mechanism of human resources are the decisive factors for the stability, growth and sustainable development of enterprises, and the key to the survival of enterprises. Due to the factors of history, culture, economy, especially the system, there are many problems in the human resources of the state-owned enterprises, which will affect the long-term development of the enterprises.
\end{abstract}

\section{Introduction}

With the development of society and economy, human resource, as the most precious resource, plays an increasingly important role in enterprise management. As the pillar of our national economy, state-owned enterprises must attach importance to human resource management if they want to survive and develop in the increasingly fierce market competition.

\section{The present situation and problems of Human Resource Management in State-owned Enterprises}

In the early stage of reform and opening up, under the old management system and extensive management mode, the state-owned enterprises always had the problem of overpopulation and inefficiency. With the rapid development of Chinese economy, state-owned enterprises are also making progress in human resource management. Especially in the new century, under the guidance of the new scientific concept of development, the CPC Central Committee has proposed to change the extensive economic growth mode, adhere to the major strategic thinking of sustainable development, in the talent planning, talent development. The introduction of a series of important policies in the field of talent training has promoted the development of the theory of human resources management in state-owned enterprises. In addition, the state-owned enterprises have made certain progress in the development and management of human resources.

First, the concept of human resources management is backward. Although many state-owned enterprises have set up human resources departments in terms of organizational structure, they have not yet completely changed their concepts from personnel management to human resources development and management. The use of human resources is relatively extensive and laissez-faire. Still remain in "personnel management", ignore the capitalization of human resources, and ignore 
the initiative of employees as individuals. The adoption of performance, appraisal, incentive, restraint and other means is still in the past footsteps, the reasonable flow of talent and the lack of competition mechanism, failed to establish an effective human resources development and management of security, investment, and performance test nuclear regime.

Second, the inflexibility or invalidation of the incentive mechanism dampens the enthusiasm of human capital. Lack of incentive is the biggest problem in state-owned enterprises. The failure of state-owned enterprises to design a scientific salary structure and effectively link it with employee performance has resulted in insufficient incentives and a series of serious consequences, such as the outflow of personnel and the inefficiency of enterprises caused by employees' inability to attend work.

Third, competition, assessment, and supervision measures are difficult to implement. The superior departments of the enterprises appoint the managers of the state-owned enterprises, and the superior departments in charge mainly carry out their assessment work. This assessment system emphasizes the political quality, neglects the requirements of the management quality, and the time span of the assessment is long, and is often not necessary and is often not necessary and The supervision function of the time and the lack of the performance assessment system make the assessment lack the scientific basis. Naturally, it cannot be a prerequisite for the competition and elimination of talent and incentive, and of course, it does not promote the development and management of human resources.

Fourth, it also caused by the historical reasons of the state-owned enterprises. Due to the constraints of the mechanism, the speed and level of talent absorption, and the attitude and means of replacing the old and the new are extremely slow and negative. Their knowledge is old and conservative, and after the introduction of new people, the obstacles to the promotion of seniority are, "everyone has a job," The idea of "everyone has a meal" and the old employees have the advantage of maintaining their qualifications makes the structure of the new and old employees unable to be adjusted reasonably. In addition, in recent years, in order to solve the problem of employment of workers' children, A large number of skilled old workers have retired early, and many children of workers who have not received higher education or vocational training have been placed in, which makes the quality of workers and staff in state-owned enterprises worrisome.

Fifth, Workers lack of urgently needed talents, especially high-level, high-skilled and complex talents in the new situation. In state-owned enterprises, due to the backward concept and system, the brain drain is serious. The managers in urgent need of enterprise development, scientific and technological talents, and even the backbone technical workers are all seriously lacking, while some other positions are generally redundant, which makes the strategy of strengthening talents difficult to carry out.

\section{Basic Countermeasures for strengthening Human Resources Management in State-owned Enterprises}

Modern human resource management organization should be able to determine what kind of talents. The enterprise needs in the development stage, to find talents, retain and develop the talents in time, to effectively configure the human resources of the enterprise, to provide strong human resources support for the strong and strong life force of the enterprise, and to ensure the management of the enterprise. The personnel engaged in human resource management should be professional management personnel trained by the human resources management profession, have the knowledge and ability of human resource management, know how to develop the human resources in the enterprise, how to introduce the urgent human resources and master the motivating staff. Principles and methods, know how to motivate employees to achieve the common development of employee interests and corporate interests. Such a professional team of human resources management is a necessary condition to promote the reform of human resources management. Human resources are the most precious and important resources in modern enterprises, and the first factor to promote the development of national economy. This paper discusses the new strategy of human resources management in state-owned enterprises, and promotes the construction 
of modern enterprise system in state-owned enterprises. This has important realistic function and guiding significance for the construction and sustainable development of the core competence of state-owned enterprises.

First, adhere to the people-oriented; strengthen the management of people-oriented. Human-oriented management is the internal requirement of modern enterprise system. Under the condition of market economy, the state-owned enterprises take the establishment of modern enterprise system as the goal of reform, which is bound to require socialized management, that is, the participation of everyone in management. Although the school of modern enterprise management theory has different starting points and different angles of expressing problems, the core of their theories is the same: that is, to emphasize the management with "human" as the center. In order to improve the economic and social benefits of the enterprises and the market competition ability of the enterprises, the state-owned enterprises must mobilize the positive factors in all aspects and explore the potential of each employee.

Second, do a good job of human resources planning; strengthen the integration of enterprise human resources. Human resource planning is one of the most basic activities in human resource management. In order to do human resource planning well, we must first forecast the demand of human resources, predict the quantity and category of human resources needed by enterprises, and analyze the internal and external labor market. Based on prediction and analysis, a series of integrated human resource planning schemes formulated to balance the supply and demand of human resources. Because of scientific planning, we should push forward the human resource strategy of enterprises, establish a scientific, effective and sound human resources management mechanism, and form a rational flow of talents.

Third, establish a scientific and sound employee performance to form an effective employee incentive mechanism. In order to establish employee performance, first, the performance appraisal system, standard and process should establish in line with the actual situation of the enterprise. In addition to formulating a general assessment standard, the classification and evaluation of personnel should also be based on the post and responsibilities of the personnel, and the detailed rules for the appraisal shall be drawn up according to the senior management, middle management, professional and technical personnel and technical workers, respectively, so that self-assessment may be carried out. At the same time, indicators should be as quantitative as possible. Establish feedback system to reduce evaluation error and root According to the actual situation changes; continuously perfect the appraisal system and the method, in order to maintain its validity. In addition, the state-owned enterprises should design a complete performance appraisal process in advance according to the actual situation of the enterprises, so that the appraisal process and results are open and transparent. Second, there should be flexible and rich incentives. In addition to general wages and benefits, companies can provide equity and option incentives to employees who have outstanding contributions, especially to those who are in urgent need of hi-tech personnel. Second, The Company's goals linked to the personal development of employees. Third, Spiritual incentives should include respect for employees in addition to giving them all kinds of honors Emphasis, understanding and support, trust and tolerance, care and consideration. Fourth, Managers should learn to enable employees to find their own business, actively participate in business management, and common development with enterprises.

Fourth, Workers establish modern enterprise professional, although the market-oriented allocation of managers in our country has only just begun and the relevant market rules have yet to established, the rapid development of social economy requires us to speed up the training of professional managers and strengthen the building of professional managers. Promote state-owned enterprise managers to achieve market allocation.

These needs to do well in the following aspects: attach importance to the scientific nature, rationality, fairness and openness of the employment of state-owned enterprise managers. Second, standardize and institutionalize the salary incentives of the managers of state-owned enterprises. Third, to accelerate the formation of an effective system for evaluating the performance of state-owned enterprise operators, only by establishing a set of scientific and objective performance 
evaluation system can the incentive mechanism of SOE managers be set up.

Fifth, establish and cultivate excellent corporate culture. Corporate culture is a common cultural view, which gradually formed in the long-term production and management practice. It is the collective consciousness and code of conduct of the enterprise initiated by the enterprise leaders and recognized by all the staff and workers. It dominates the behavior of the enterprise and its employees. Corporate culture unifies the management and use of human resources in a common guiding ideology and management philosophy, thus motivating employees to work together to achieve common goals. There is a significant relationship between human resources strategic management and human resources management, human resources management scholar Xia Li In order to be effective, the enterprise culture must supported by the corporate culture and at the same time, it should be supported by the continuance of the corporate culture. She stressed that corporate culture can constitute a dynamic source of human resources management activities, and that the influence of corporate culture is omnipresent in human resources strategic management activities. Establishing and cultivating corporate culture is one of the basic tasks of human resource management. Corporate culture is a new stage in the development of human social management ideology. Excellent corporate culture will play a more important role in people's enthusiasm, initiative, orientation and creativity in their work. . For most state-owned enterprises, the focus of enterprise culture construction is to lift the shackles of old ideas, customs and institutions.

In the construction of corporate culture, we can learn from the western developed countries in the design and shaping of corporate image has established a set of systematic theory and techniques-enterprise identification system (CIS). From the construction of a unified enterprise concept, standardized enterprise behavior, starting with the consistent visual image of the enterprise, the strong corporate culture plays a guiding, cohesive and motivating role to the employee's behavior. This is also the important mission of modern human resource management.

\section{Summary}

If the state-owned enterprises want to survive and develop in the fierce market competition, they must attach importance to the training and development of human resources. This is also an important link in the reform of human resources management in state-owned enterprises. Training should be an investment with high rate of return, which can improve the quality of human resources and bring effect to the growth of enterprise benefit. Therefore, according to the changes of the enterprise environment and the requirements of the enterprise's own development, the human resources department should formulate the long-term human resources training plan and provide all kinds of training projects. From training in marketing, technical skills and culture, values to training in computer technology and interpersonal communication and leadership skills, training projects should based on the prospects and strategies of the enterprise and the stage of development of the enterprise, the industry characteristics of the enterprise, the quality of the staff and management level of development to arrange. At the same time, we should establish a scientific and reasonable training evaluation system.

In a word, the human resource management of state-owned enterprises is a complex system project, and many of its problems not formed by chance. Its perfect process is not likely to achieve overnight. It requires the guidance and standardization of the national macro policies and laws and regulations, and the practical and effective internal reform of the state-owned enterprises, and the human resources of modern science. The resource management system makes human resource management strategy the first strategy for state-owned enterprises to seek development and continuously enhance the core competitiveness of state-owned enterprises.

\section{References}

[1] B X. The way of the transition from traditional personnel Management to Modern Management [J]. Modern Enterprises 2007 (10).

[2] Liu Y f. Problems and Countermeasures of Human Resource Management in State-owned 
Enterprises [J]. Talent Resources Development 2015 (2).

[3] X Min. Application of incentive Mechanism in Human Resource Management of State-owned Enterprises [J]. China Business \& Trade 2014 (28).

[4] Mao Jun. Strategic analysis of human resources management in state-owned enterprises [J]. Human resource development, 2016 (12).

[5] Zhang De. Human resources development and management [M]. Tsinghua University press, 2003.

[6] David Warlike. Human resources tutorials [M]. Xinhua Publishing House.

[7] R. Wayne Mondi. Human resources management [M]. Economic Science Press, China.

[8] Chen Lei. Problems and Countermeasures in Financial Management of State-owned Enterprises [J]. Occupational Circle 2007 (14)

[9] Ni Qing. Analysis of Human Resource Management in State-owned Enterprises [J]. Enterprise economy 2008 (10) 